\title{
THE RELATIONSHIP BET WEEN SPORTS ENGAGEMENT, BODY MASS INDEX AND PHYSICAL ABILITIES IN CHILDREN
}

Predrag Lazarevic ${ }^{1}$, Vladimir Zivkovic ${ }^{1}$, Milena Vuletic ${ }^{1}$, Nevena Barudzic ${ }^{1}$ and Dejan Cubrilo ${ }^{1}$ ${ }^{1}$ Department for Physical Education, Faculty of Medicine, University of Kragujevac, Kragujevac

\section{ABSTRACT}

Hypokinesia, which is a consequence of modern technological development, is now one of the three biggest health risk factors. Whereas physical inactivity and obesity in adults is subject of concern, these factors in children presage an even greater public health problem because many health-related problems and life-threatening diseases begin in childhood and adolescence.

It has been noted that regular physical activity modulates vascular endothelial function via an effect on basal nitric oxide (NO) production, thus leading to a significant reduction in the incidence of cardiovascular disease (1). Exercise can also increase energy expenditure and can create a negative energy balance. Conversely, scientific data regarding the effect of school-based physical activity interventions on body mass index (BMI) in children are conflicting (2, 3). Moreover, there is insufficient clinically useful scientific data on BMI in children and its possible association with motor skills. With both sexes, motor abilities improve from physical development in adolescents, and regular sports training influences fitness and motor abilities.

The aim of our study was to evaluate the morphological status and physical abilities of 13-year-old children in order to investigate the relationship between sports engagement, $B M I$ and physical abilities. The results of our study should give coaches important parameters in the selection of young athletes, as well as provide them with information that may be useful in training and programming assignments.

\section{MATERIALS AND METHODS}

The research was carried out with a group of 67 boys from an elementary school. The boys were $12-13$ years old and had differing sports training experiences.

After an assessment of morphological characteristics (height, weight, BMI), the children were subjected to a battery of motor tests designed to test speed and coordination (Jumping and going through Swedish boxes, slalom with 3 balls, hand tapping, 50-m sprint, 30-m flying start sprint and 20-m slalom sprint (4)).

\section{RESULTS AND DISCUSSION}

The average BMI of the children who participated in the study was $19.2 \pm 3.4$. After transforming BMI data to appropriate percentiles according to the formulas proposed by the National Center for Health Statistics of United States (5), we classified each subject into one of four groups: underweight (athletes vs. non-athletes: $7.7 \%$ vs. $17.8 \%)$, healthy weight $(69.2 \%$ vs. $46.4 \%)$, overweight (12.8\% vs. $21.4 \%)$ and obese (10.2\% vs. $14.3 \%)$. Although $\mathrm{BMI}$ is thought to measure excess weight rather than excess body fat, if appropriate cut-off points are used, a high BMI level is a moderately sensitive and very specific indicator of excess adiposity among children (6).

Since hypokinesis in children and adolescents is thought to be a growing problem, especially in urban places, it is encouraging that $58.2 \%$ of the boys in the study stated that they participated in a sport activity. To determine if sport activity influences morphological status of young 13year-old boys, we applied a contingency analysis ( $\chi^{2}$-test) and found no significant difference between children who train for a sport and those that do not. These results are in agreement with many other studies that have found that, in contrast to biological growth, the absence of involvement in sports activities in children is not the main factor that influences their morphological status and physical fitness. Moreover, an analysis of morpho-functional skills of young 
teens and premature soccer players (14 and 15 vs. 16 and 17 year olds) revealed that the aerobic capacity $\left(\mathrm{VO}_{2} \max \right)$ and BMI significantly changed with age, but not with the training experience of the examined athletes (7).

Regarding the influence of morphological status of 13-year-old boys on motor performance, the results of our study suggest that morphological status, estimated by BMI, is an important predictor of physical abilities in children. This finding is in agreement with the results of other studies (8). Discriminative analysis (Kruskal-Wallis test, Table 1) showed that subjects with different morphological status had significantly different performance in 5 out of the 6 tests performed, of which two were designed to test speed and three tested coordination. However, canonical discrimination, used to determine the influence of morphological status on latent motor function, showed significant differences only in coordination tests.

Regarding the influence of sports engagement on motor performance in our participants, a Man-Whitney test (Table 2) showed that, compared with those that did not train, boys who train for a sport had significantly better results only in 2 motor tests, which were confirmed by factor analysis to be valid tests of coordination. These results suggest that the morphological status of 13-year-old children better predicts coordination performance than speed performance.

The results of our study suggest that involvement of adolescents in sport activities has much less influence on motor abilities than that of natural biological growth and maturation. The age at which the boys in this study were tested falls within the first phase of adolescence, which is characterised by sudden and intermittent skeletal maturation without being followed by adequate skeletal muscle development. That is one of the reasons why boys of this age experience a fall in coordination performance. In other words, motor development in 13-year-old boys does not depend on training experience but instead relies on genetics and acceleration of growth.

It should be emphasised that the small number of participants in this study limited our ability to make any significant anthropological generalisations. However, the sample size did not affect the ability to address the main aim of this study, which was to assess the predictive value of morphological status and involvement in sports as parameters that affect motor performance.

\begin{tabular}{|l|l|l|l|}
\hline Variable & $\begin{array}{l}\text { Ath- } \\
\text { letes }\end{array}$ & $\begin{array}{l}\text { Non- } \\
\text { athletes }\end{array}$ & Sig. \\
\hline $\begin{array}{l}\text { Jumping and going through } \\
\text { Swedish boxes (sec) }\end{array}$ & 15.85 & 16.58 & .097 \\
\hline Hand tapping (taps) & 69.28 & 64.07 & $.018^{*}$ \\
\hline Slalom with 3 balls (sec) & 22.04 & 25.86 & $.004^{*}$ \\
\hline 50-m sprint (sec) & 9.24 & 9.49 & .088 \\
\hline 30-m flying start sprint (sec) & 5.38 & 5.50 & .065 \\
\hline 20-m slalom sprint (sec) & 4.76 & 4.88 & .132 \\
\hline
\end{tabular}

Table 2. Mean values of results that boys who train or do not train some sport achieved on motor tests.

\section{REFERENCES}

1. Green DJ, Maiorana A, O'Driscoll G, Taylor R. Effect of exercise training on endothelium-derived nitric oxide function in humans. J Physiol 2004; 561:1-25.

2. Lazaar N, Aucouturier J, Ratel S, Rance M, Meyer M, Duché P. Effect of physical activity intervention on body composition in young children: influence of body mass index status and gender. Acta Paediatr 2007; 96(9): 315-20.

3. Harris KC, Kuramoto LK, Schulzer M, Retallack JE. Effect of school-based physical activity interventions on body mass index in children: a meta-analysis. CMAJ 2009; 180(7):719-26.

4. Perić D. Operationalisation of research in sports and physical education. Beograd: Politop-p, 1994. (In Serbian)

5. National Center for Health Statistics of United States (2009): CDC Growth Charts. www. cdc.gov/childrens_BMI

6. Freedman DS, Ogden CL, Berenson GS, Horlick M. Body mass index and body fatness in childhood. Curr Opin Clin Nutr Metab Care 2005; 8(6): 618-23.

7. Cubrilo D: Systemic effects of redox balance disturbance caused by the intensive training of young soccer players, PhD dissertation, Medical faculty, University of Kragujevac, Serbia, 2009.

8. Manić G. Multivariant differencies of some biomechanical dimensions of elementary school children in relation to amount of fat tissue. Kinesiologica 2007; 1: 44-48. (in Croatian)

Table 1. Mean values of results that subjects with different morphological status achieved on motor tests.

\begin{tabular}{|l|l|l|l|l|l|}
\hline Variable & Underweight & $\begin{array}{l}\text { Healthy } \\
\text { weight }\end{array}$ & Overweight & Obese & Sig. \\
\hline $\begin{array}{l}\text { Jumping and going through } \\
\text { Swedish boxes (sec) }\end{array}$ & 15.60 & 15.37 & 17.59 & 20.23 & $.000^{*}$ \\
\hline Hand tapping (taps) & 60.00 & 69.00 & 73.09 & 73.75 & $.040^{*}$ \\
\hline Slalom with 3 balls(sec) & 28.65 & 22.26 & 21.61 & 28.29 & $.004^{*}$ \\
\hline 50-m sprint (sec) & 9.90 & 9.15 & 9.47 & 10.28 & $.002^{*}$ \\
\hline 30-m flying start sprint (sec) & 5.82 & 5.37 & 5,53 & 6.01 & $.008^{*}$ \\
\hline 20-m slalom sprint (sec) & 5.03 & 4.77 & 4.97 & 5.05 & .204 \\
\hline
\end{tabular}

